\title{
The prediction of the teaching readiness level of pre-service teachers in terms of curriculum literacy
}

\author{
Hanife Esen Aygün ${ }^{* a}$ \\ ${ }^{a}$ Çanakkale Onsekiz Mart University, Faculty of Education, Çanakkale/Turkey
}

Article Info

DOI: 10.31704/ijocis.2019.009

Article History:

Received 11 February 2019

Revised 01 October 2019

Accepted 05 October 2019

Online 26 December 2019

\section{Keywords:}

Curriculum literacy,

Teacher readiness,

Pre-service teacher,

Teacher training.

Article Type:

Research paper

\begin{abstract}
Curriculum literacy is in the forefront to increase the professional competence of teachers. Based on this, the study focuses on the extent of pre-service teachers' curriculum literacy level on their teacher readiness. The study is designed in a predictive correlation model. Thus, it is focused on whether pre-service teachers' curriculum literacy is a meaningful predictor of the level of readiness for the teaching profession or not. 708 pre-service teachers participated in the research who studies in Primary Teacher Training, Pre-school Teacher Training, Turkish Teacher Training, English Teacher Training, Psychological Counselling and Guidance Training, Computer Teaching and Technology Education Training and Science Teacher Training Department. The findings indicate that the pre-service teacher curriculum literacy and readiness for teaching profession are at the level of "Agree". Finally, it is shown that pre-service teachers' curriculum literacy level predicts their teacher readiness level for teaching profession.
\end{abstract}

\section{Öğretmen adaylarının öğretmenlik mesleği hazırbulunuşluk düzeyinin eğitim programı okuryazarlığı açııından yordanması}

Makale Bilgisi

DOI: $10.31704 /$ ijocis.2019.009

Makale Geçmişi:

Geliş $\quad 11$ Şubat 2019

Düzeltme 01 Ekim 2019

Kabul 05 Ekim 2019

Çevrimiçi 26 Aralık 2019

Anahtar Kelimeler:

Eğitim programı okuryazarlığı,

Öğretmen hazırbulunuşluğu,

Öğretmen adayı,

Öğretmen eğitimi.

Makale Türü:

Özgün Makale
Öz

Eğitim programı okuryazarlığı öğretmenlerin mesleki yetkinliğini arttırmada oldukça önemli bir husustur. Buna bağlı olarak bu araştırmada, öğretmen adaylarının eğitim programı okuryazarlık düzeylerinin mesleki hazırbulunuşluk düzeyini ne ölçüde yordadığına odaklanılmıştır. Bu doğrultuda, araştırma yordayıcı korelasyonel modelde gerçekleştirilmiştir. Araştırmaya Sınıf Eğitimi, Okul Öncesi Eğitimi, Türkçe Eğitimi, İngilizce Eğitimi, Psikolojik Danışmanlık ve Rehberlik Eğitimi, Bilgisayar Öğretmenliği ve Teknoloji Eğitimi ve Fen Bilgisi Eğitim Anabilim Dalı'nda öğrenim gören 708 öğretmen adayı katılmıştır. Bulgular, araştırmaya katılan öğretmen adaylarının eğitim programı okuryazarlığının ve öğretmenlik mesleğine hazırbulunuşluğun "Katılıyorum" düzeyinde olduğuna işaret etmektedir. Sonuç olarak, bulgular eğitim programı okuryazarlığının öğretmenlik mesleğine hazırbulunuşluk düzeyini anlamlı düzeyde yordadığına işaret etmektedir. 


\section{Introduction}

Teachers play an important role in reaching the output of educational programs (Büyükkaragöz, Muşta, Yılmaz \& Pilten, 1998; Kaptan, 1999). Therefore, it is necessary that pre-service teachers should be ready for the profession as qualified and equipped as possible (Güven-Yıldırım \& Köklükaya, 2017). This is more about the fact that teachers' professional competence affects the quality of education (Başal \& Taner, 2003). Accordingly, teacher training programs offer diverse experiences in preparing pre-service teacher for the teaching profession (Tatto, Lerman \& Novotta, 2009). However, it is seen that most of the pre-service teachers have various concerns about to be ready for the teaching profession (Akgün \& Özgür, 2014; Doğan \& Çoban, 2009; Karakaya, Avgın, Gömlek \& Balık, 2017; Saracaloğlu, Kumral \& Kanma, 2009).

Responding appropriately to the needs of their students, classroom management, dealing with other problems of the profession, overcoming the daily problems caused by school life are basically teachers` main concerns during their initial years of their teaching due to limited exposure to professional experience at their teacher training (Arslan \& Özpınar, 2008; Stanulis, Fallona \& Pearson, 2002; Thomas \& Kiley, 1994). This seems to be the reason for pre-service teachers leaving teaching in the first years of their careers (Thomas \& Kiley, 1994). It is thought that this tendency is related to whether pre-service teachers and teachers are ready for the teaching profession or not. Researchers describe the teacher education graduate as ready to teach professionally equipped with the professional qualifications to deal with the professional difficulties (Black, 2003; Mehmetlioğlu \& Haser, 2013) and explains the readiness for pre-service teachers by the concept of feeling ready to work (Mehmetlioğlu \& Haser, 2013). Readiness for teaching profession plays an important role in the quality of teaching (Housego, 1990) and pre-service teachers ready for the teaching profession are faced with fewer problems in classroom management (Li, 1999).

One of the main aims of teacher education is to equip pre-service teachers with the necessary skills which are general culture, field of knowledge and teaching professing knowledge (Demirel, 2012) oriented for effective teaching in different settings (Flores, 2018). However, curriculum literacy is in the forefront to increase the professional competence of teachers (Bolat, 2017). While some researchers define the literacy program as the capacity to have knowledge about the curriculum, to interpret the program, to develop a critical point of view and to implement the curriculum in accordance with the learning environment (Keskin \& Korkmaz, 2017), some of them define it as the ability of teachers to fulfil educational program literacy by themselves (Erdem \& Eğmir, 2018). Unlike these definitions, it is seen that some researchers define the literacy program as the capacity of the teacher to adapt the program to new situations (Nsibande \& Modiba, 2012). In sum, it is considered that a teacher who is able to define the curriculum effectively in the fields of output, content, learning-teaching processes and measurement and evaluation is more successful in teaching is ready for teaching. Based on this information regarding teacher competencies, it is thought that pre-service teachers who are highly curriculum literate are more positive for the teaching profession. It is thought that this situation will contribute positively to the quality of learning-teaching process.

In the literature, there are various studies about both teacher readiness (Şahin \& Küçüksüleymanoğlu, 2015) and curriculum literacy (Beck, 2013; Bolat, 2017; Karseth \& Sivesind, 2010). It is seen that a significant part of those studies on teacher readiness are related to pre-service teachers' readiness for self-management learning (Karataş, 2017; Karataş \& Başbay, 2014; Şahin, 2010; Şahin \& Küçüksüleymanoğlu, 2015) or for teaching on their own (Özbek, Eroğlu \& Donmuş, 2017; Salaş, 2010) or for technology teaching (Hung, 2016; Instefjord \& Munthe, 2016; Msila, 2015; Oliver, 2010; Singh \& Chan, 2014) or for mathematics and science teaching (Alkan \& Erdem, 2013; Ng, 2013; Steele, Brew, Rees \& Ibrahim-Khan, 2013). To the best of these researchers' knowledge, there are not any studies focusing on the relationship between teacher readiness and their curriculum literacy. Research has drawn attention to the fact that teachers who are ready for teaching recognize and effectively implement the curriculum (Ingvarson, Beavis \& Kleinhenz, 2007). Accordingly, it is considered that a teacher who is able to identify and effectively implement the curriculum is ready for the teaching profession. Based on this information, this study focuses on the role pre-service teachers' curriculum literacy level in predicting their readiness for the teaching profession. In this respect, the research questions are as follows:

1. What is the level of pre-service teachers' curriculum literacy and their teacher readiness?

2. Is there a significant difference in terms of teacher's readiness for pre-service teachers' department, grade level and gender? 
3. Is there a significant difference in terms of curriculum literacy for pre-service teachers' department, grade level and gender?

4. Is there a relationship between pre-service teachers' curriculum literacy and readiness for the teaching profession?

5. Are the levels of pre-service teachers' curriculum literacy a meaningful predictor of the level of readiness for the teaching profession?

\section{Method}

This predictive correlation model study focuses on the relationship between pre-service teachers' readiness levels for the teaching profession and curriculum literacy levels (Büyüköztürk, Çakmak, Akgün, Karadeniz \& Demirel, 2012). In this respect, this study examines whether pre-service teachers' curriculum literacy levels significantly predict their readiness for the teaching profession

\section{Sample}

Population consisted of pre-service teachers at a university located in the Marmara Region in Turkey. Stratified sampling technique was used to identify the participants (Büyüköztürk et al., 2012). A 95\% confidence interval was accepted for the sample to represent the population, and the formula suggested by Krejcie and Morgan (1970) for determining sample size was used. The study was conducted in the Faculty of Education in which approximately 3800 pre-service teachers were studying. However, the total number of teacher candidates studying in the third and fourth grades was 1524. According to the aforementioned formula, a sample of 310 people was proposed for the population size of 1600 people. However, 708 pre-service teachers participated in the study because of the fact that the class level was also examined in the study and that the number of some of the departments was higher than the others. In addition, after briefly explaining the aim of the research, it was ensured that those who volunteered to participate in the study completed the scales. Participants' percentage values and number according to the department they were studying are as in Table 1:

Table 1.

Number and Percent Distribution of Sampling by Department.

\begin{tabular}{lrrr}
\hline & & \multicolumn{2}{c}{ Sample } \\
\cline { 2 - 4 } Department & Population & $\mathbf{f}$ & $\%$ \\
\hline Primary Teacher Training & 271 & 211 & 29.40 \\
Pre-school Teacher Training & 306 & 81 & 11.30 \\
Turkish Teacher Training & 205 & 12.30 \\
English Teacher Training & 199 & 14.80 \\
Psychological Counselling and Guidance Training & 196 & 108 \\
Computer Teaching and Technology Education Training & 175 & 94 & 13.30 \\
Science Teacher Training & 172 & 46 & 7.80 \\
Total & 1524 & 80 & 11.10 \\
\hline
\end{tabular}

In total, 708 pre-service teachers participated in the research who studied in several departments as indicated in Table 1. 423 of the pre-service teachers were female while 285 were male. In addition, 364 of the pre-service teachers who participated in the study were studying in the fourth grade, while 344 were studying in the third grade.

\section{Data Collecting Tools and Procedure}

Curriculum Literacy Scale (Bolat, 2017) and Teacher Readiness for Teaching Profession Scale (Güven-Yıldırım \& Köklükaya, 2017) were employed to collect data. These scales were administered to volunteered participants of this study at their during the spring semester of 2017-2018 academic year.

Curriculum Literacy Scale (CLS). This scale which was developed to determine the curriculum literacy of teacher candidates. The scale is consists of 29 items. Explanatory and confirmatory factor analysis was used to ensure the validity of the measurement tool. As a result of the tests performed, it was seen that the scale was collected in two factor set above the factor load of .40. These factors are called Reading and Writing. The confirmatory factor analysis was applied to test the construct validity of the scale indicates that the fit indices were good $\left(\mathrm{X}^{2}=657.80 ; \mathrm{p}<.05 ; \mathrm{sd}=.38 ; \mathrm{RMSEA}=.06 ; \mathrm{SRMR}=.05 ; \mathrm{NFI}=.94 ; \mathrm{NNFI}=.97 ; \mathrm{CFI}=.97 ; \mathrm{IFI}=.97 ; \mathrm{GFI}\right.$ $=.83 ; \mathrm{AGFI}=.80$ ). As a result of the reliability analysis conducted to test the internal consistency of the scale, 
the Cronbach Alpha coefficient was calculated as .88 for the reading factor, .90 for the writing factor and .94 for the whole scale. Participants responded by using expressions such as 'I completely agree', 'Very agree', 'I agree at a moderate level', 'I agree a lot', 'I do not agree with the items', in a 5-Likert type measure. The scale can be pointed as 1.00-1.80= Strongly disagree; $1.81-2.60=$ Disagree; $2.61-3.40=$ Undecided; 3.41-4.20= Agree; 4.21-5.00= Strongly Agree.

Teacher Readiness for Teaching Profession Scale (TRTPS). This scale, which was developed in order to determine the readiness levels of the pre-service teacher towards the teaching profession, consists of 30 items. In order to ensure the validity of the measurement tool, basic components have been used in factor analysis. Thus, items with a factor load greater than .45 were found to be collected in two sub-factors. As a result of the reliability analysis, Cronbach Alpha coefficient was calculated as .95 for the first factor, .78 for the second factor and .93 for the whole scale as a result of testing the internal consistency of the scale. This indicates that the instrument is valid and reliable in determining the level of readiness for teaching profession. The measuring tool is a 5-Likert type. In this direction, the participant responds to the items through strongly agree, agree, undecided, disagree and strongly disagree statements. Scale can be pointed as 1.00-1.80: Strongly Disagree; Very Low; 1.81-2.60: Disagree; Low; 2.61-3.40: Undecided; Mid; 3.41-4.20: Agree; High; 4.21-5.00: Strongly Agree; Very High.

\section{Data Analysis}

In the analysis of the research data, the suitability of the normal distribution of the data set was examined first. Findings related to the normality of the data set are as in Table 2.

\section{Table 2.}

Kolmogorov-Smirnov Test Results.

\begin{tabular}{lrrr}
\hline Scale & Statistic & df & Sig. \\
\hline Curriculum Literacy Scale & .04 & 708 & .20 \\
Teacher Readiness for Teaching Profession Scale & .05 & 708 & .11 \\
\hline
\end{tabular}

The Kolmogorov-Smirnov test was applied because the number of pre-service teachers participating in the research was greater than 29 (Kalaycı, 2010). As a result of the analysis, it was understood that the data set had normal distribution, $p>.05$ (Field, 2007; Tabachnick \& Fidell, 2007). Thus, it was decided that the use of parametric tests was appropriate. T-test was used in the analysis of the data related to gender and class level, and variance analysis was used in the analysis of the data related to the department. Pearson Correlation coefficient was calculated when the relation of teacher readiness and curriculum literacy was examined. In order to explore whether pre-service teachers' curriculum literacy levels predict their readiness for the teaching profession or not, a simple regression model was employed.

\section{Results}

Pre-service teachers' levels for the curriculum literacy and teaching profession are as shown in Table 3.

Table 3.

Results of the Descriptive Statistics on CLS and TRTPS Points.

\begin{tabular}{lrrrrrr}
\hline Variable & $\mathbf{N}$ & Min. & Max. & Variance & sd. & $\overline{\mathbf{x}}$ \\
\hline CLS & 708 & 2.03 & 5.00 & .29 & .54 & 3.93 \\
TRTPS & 708 & 1.30 & 5.00 & .25 & .50 & 3.96 \\
\hline
\end{tabular}

The answers of the pre-service teachers' curriculum literacy level was at the level of Agree $(\bar{x}=3.93)$ and their teacher readiness level for teaching profession was at the level of Agree $(\bar{x}=3.96)$. The analysis of the responses of the pre-service teachers to the scales were analysed according to the gender variable are presented in Table 4. 
Table 4.

T-test Results of the CLS and TRTPS Points to Gender.

\begin{tabular}{llcccccc}
\hline Variable & Gender & $\mathbf{N}$ & $\overline{\mathbf{x}}$ & $\mathbf{s d}$ & $\mathbf{d f}$ & $\mathbf{t}$ & $\mathbf{p}$ \\
\hline CLS & Female & 423 & 3.96 & .55 & 703 & 2.18 & .03 \\
\multirow{2}{*}{ TRTPS } & Male & 285 & 3.86 & .51 & & & \\
& Female & 423 & 4.00 & .51 & 703 & 3.92 & .00 \\
& Male & 285 & 3.86 & .48 & & & \\
\hline
\end{tabular}

When Table 4 is examined, it is understood that pre-service teachers' curriculum literacy level was $t(708)=$ $2.18, \mathrm{p}<.05$ and the teacher readiness level was significantly different in favour of the female teacher candidates $\mathrm{t}(708)=3.92, \mathrm{p}<.05$.

Table 5.

Variance Analyses Results of the CLS and TRTPS Points to Department.

\begin{tabular}{|c|c|c|c|c|c|c|}
\hline Variable & & Sum of Squares & df & Mean Square & $\mathbf{F}$ & $p$ \\
\hline \multirow[t]{3}{*}{ CLS } & Between Groups & 14.30 & 7 & 2.04 & 7.41 & .00 \\
\hline & Within groups & 191.82 & 701 & .27 & & \\
\hline & Total & 206.13 & 708 & & & \\
\hline \multirow[t]{3}{*}{ TRTPS } & Between Groups & 6.54 & 7 & .93 & 3.70 & .00 \\
\hline & Within groups & 175.61 & 701 & .25 & & \\
\hline & Total & 182.15 & 708 & & & \\
\hline
\end{tabular}

Findings in Table 5 indicate that the curriculum literacy level $[(\bar{x}=4.05), F(708)=7.41, p<.05]$ and teacher readiness level $[(\bar{x}=4.08), F(708)=3.70, p<.05]$ of primary pre-service teachers were significantly different than the others.Findings based on the grades pre-service teachers' responses to the scales are in Table 6.

Table 6.

T-test Results of the CLS and TRTPS Points to Grade.

\begin{tabular}{|c|c|c|c|c|c|c|c|}
\hline Variable & Grade & $\mathbf{N}$ & $\overline{\mathbf{x}}$ & sd. & df & $\mathbf{t}$ & $p$ \\
\hline \multirow[t]{2}{*}{ CLS } & Third grade & 364 & 3.81 & .54 & 706 & 6.23 & .00 \\
\hline & Fourth grade & 344 & 4.06 & .51 & & & \\
\hline \multirow[t]{2}{*}{ TRTPS } & Third grade & 364 & 3.86 & .48 & 706 & 5.46 & .00 \\
\hline & Fourth grade & 344 & 4.07 & .51 & & & \\
\hline
\end{tabular}

When Table 6 is examined, it is understood that the curriculum literacy level of the fourth grade students $(\bar{x}$ $=4.06)$ was significantly different from that of the third grade students $(\bar{x}=3.81), t(706)=6.23, p<.05$. Similarly, it is understood that the teacher readiness of the fourth grade students to the teaching profession $(\bar{x}=4.07)$ is significantly different from that the third grade students $(\bar{x}=3.86), t(706)=5.46, p<.05$.

Table 7 presents findings related to the relationship between curriculum literacy and teacher readiness for the teaching profession.

Table 7.

Relationship between Curriculum Literacy and Teacher Readiness for Teaching Profession.

\begin{tabular}{llrr}
\hline & & CLS & OMH \\
\hline CLS & Pearson Correlation & 1.000 & $.738\left(^{* *}\right)$ \\
& Sig. (2-tailed) &. & .000 \\
\multirow{2}{*}{ TRTPS } & $\mathrm{N}$ & 708 & 708 \\
& Pearson Correlation & $.738\left(^{* *}\right)$ & 1.000 \\
& Sig. (2-tailed) & .000 &. \\
& $\mathrm{~N}$ & 708 & 708 \\
\hline
\end{tabular}

When Table 7 is examined, the relationship of the pre-service teachers' responses about the curriculum literacy and teacher readiness for the teaching profession is seen. Findings indicated that there was a high positive correlation between the pre-service teachers' curriculum literacy level and the level of teacher readiness for the teaching profession, $r=.738$ (Field, 2013). 
Table 8 shows the findings of how the curriculum literacy levels of the pre-service teachers predicted the teacher readiness for the teaching profession.

Table 8.

Simple Linear Regression Analyses Results.

\begin{tabular}{lrrrrrrr}
\hline Variable & $\mathbf{B}$ & Standard Error B & $\mathbf{R}$ & $\mathbf{R}^{2}$ & Standardized $\boldsymbol{\beta}$ & $\mathbf{t}$ & $\mathbf{F}$ \\
\hline Constant & 1.46 & .10 & .68 & .46 & .680 & 14.44 & 615.97 \\
CLS & .635 & .02 & & & & 24.81 & \\
\hline
\end{tabular}

The results of a simple linear regression analysis of the predictability of curriculum literacy as a teaching profession appear to be significant, ( $F=615.97), p>.05$. This finding, as a result of the variance analysis, indicates that the relationship between the curriculum literacy and teacher readiness for the teaching profession is linear, $R=.680, R^{2}=.462, p<.05$. It can also be said that the level of curriculum literacy is significantly important in terms of predicting the level of teacher readiness for the teaching profession in the positive direction. In other words, the curriculum literacy level accounts for $46 \%$ of the total variance in being ready for the teaching profession.

\section{Discussion, Conclusion and Implications}

The findings indicate that the pre-service teachers' level of curriculum literacy and their teacher readiness for the teaching profession was not high but at a good level. It is understood that this finding is compatible with the findings of similar studies in the literature both in terms of educational program literacy (Erdem \& Eğmir, 2018; Sural \& Dedebali, 2018) and teacher profession readiness (Mehmetlioğlu \& Haser, 2013; Şahin \& Küçüksüleymanoğlu, 2015). This is considered as positive in terms of the professional development of preservice teachers.

When the findings were examined considering the gender variables, it was understood that the female preservice teachers had higher levels of curriculum literacy and teacher readiness for the teaching profession than the male pre-service teachers. It is believed that this finding is related to the attitudes towards the teaching profession. When the research regarding the attitudes of the prospective teachers about the profession are examined, the female teacher candidates likened the teaching profession to motherhood, that their attitudes towards the profession were, therefore, more positive than the male candidates and that they preferred the teaching profession more consciously than the male candidates (Bozdoğan, Aydın \& Yıldırım, 2007; Budak \& Kula, 2017; Çapri \& Çelikkaleli, 2008; Çermik, Doğan \& Şahin, 2010; Çocuk, Yokuş \& Tanrıseven, 2015; Koç, 2014; Özsoy, Özsoy, Özkara \& Memiş, 2010; Terzi \& Tezci, 2007). In addition, it is known that pre-service teachers with positive attitudes towards the profession are more successful in their professional knowledge courses (Ekici, 2008). Based on this information, it could be said that the female pre-service teachers are more willing to become teachers and, that their awareness about vocational and field knowledge courses is, for that reason, higher than the male pre-service teachers.

When the findings were examined department based it was understood that the level of curriculum literacy and readiness of the pre-service teachers, who studied in the Department of Primary Teacher Training, are significantly department than the others. When Primary Teacher Training Programme is examined, it is seen that it includes Reading and Writing Teaching, Turkish Language Teaching, Maths Teaching, Life Science Teaching, Science and Technology Teaching, Social Science Teaching, Religion Culture and Moral Knowledge Teaching courses. These courses contribute to the pre-service teachers' curriculum knowledge and skills (Council of Higher Education, 2006). When looking at other teacher training programs, Pre-school Teacher Training, Turkish Teacher Training and Computer Teaching and Technology Education Training programmes contain a Special Teaching Methods course. In addition, English Teacher Training contains Approaches in Teaching English, Science Teacher Training program contains Science-Technology Program and Planning, Psychological Counselling and Guidance Training contains Curriculum Development in Guidance in addition to Special Teaching Methods course. The pre-service teachers examine specific instructional programs in these courses (Council of Higher Education, 2006). Primary pre-service teachers' teacher readiness level is higher than the other pre-service teachers. This is thought to be due to their intense exposure to field-specific and curriculum literacy opportunity of the primary pre-service teachers helps them feel ready for the teaching profession. It is noteworthy that the pre-service teachers who are successful in field education courses have more positive teaching competence perception (Çaycı, 2011; Ekici, 2008). Therefore, it is understood that the obtained result is compatible with similar studies. 
Another finding in this study was that the readiness and curriculum literacy levels of the pre-service teachers in the fourth grade were significantly different from those of the third graders. It is understood that the result obtained is in parallel with the results of similar studies (Housego, 1992; Mehmetlioğlu \& Haser, 2013). This is thought to be due to the positive contributions of the Teaching Practice courses. In teaching practice course, the pre-service teachers restructure their knowledge in many aspects of the teaching profession throughout their undergraduate studies and in their practice schools (Karadüz, Eser, Şahin \& ilbay, 2009). As a result, the pre-service teachers both plan the practice lessons and implement it by using the knowledge they acquire about curriculum in field education courses. Therefore, it is thought that the levels of high curriculum literacy and high teacher readiness of the pre-service teachers in the fourth grade are related to this situation.

In this research, the relationship between curriculum literacy and teacher readiness for the teaching profession was examined. It is noteworthy that there is a high positive correlation between curriculum literacy and readiness for the teaching profession and that curriculum literacy predicts teacher readiness for the teaching profession. As stated earlier, the teacher, who is ready for work, defines himself/herself as having the professional qualifications (Mehmetlioğlu \& Haser, 2013). In addition, when the General Competencies of Teacher Profession were examined, teachers with professional knowledge and professional skills described teacher as a person "who had curriculum and pedagogical knowledge regarding their field", "who effectively planned education and training processes", "who prepared appropriate learning materials with healthy and safe learning environments for effective learning for all students", "who effectively executed the learning and teaching process" and "who suitably use[s] teacher measurement and evaluation methods, techniques and tools" (General Directorate of Teacher Training and Development, 2017). Based on this, it is thought that the defined teacher competencies are related to curriculum literacy. Because curriculum program literacy is one of the dimensions of the adequacy of the teacher (Bolat, 2017).

As a result, when the findings obtained from the research were evaluated in general, it was seen that the readiness and curriculum literacy levels of pre-service teachers increased when they focused on curricular study more. In addition, fieldwork, like teaching practice, played a role in the pre-service teachers' curriculum literacy and teacher readiness levels. Accordingly, pre-service teachers' curriculum literacy levels were predicated on being ready for the teaching profession. Namely, pre-service teachers who were highly knowledgeable and skilled in the field-specific curriculum felt ready to work.

When the literature is examined, it is noteworthy that studies mainly geared to explore the relation between professional competences and teacher readiness. It is thought that this study, which focuses on teacher readiness and curriculum literacy, is original and will contribute to the field. Based on the findings of this study, it is recommended to examine the readiness of field-specific curriculum literacy on the role of teacher readiness. 


\section{TÜRKÇE SÜRÜM}

\section{Giriş}

Eğitim programlarının çıktılarına ulaşılmasında öğretmenlerin önemli rol oynadığı bilinmektedir (Büyükkaragöz, Muşta, Yılmaz \& Pilten, 1998; Kaptan, 1999). Bu nedenle, öğretmen adaylarının çağın gereksinimine uygun yeterlilik ve donanım sahibi olarak mesleğe hazır olmaları gerekmektedir (Güven-Yıldırım \& Köklükaya, 2017). Çünkü öğretmenlerin mesleki yeterliği eğitimin niteliğini etkilemektedir (Başal \& Taner, 2003). Buna bağlı olarak, öğretmen eğitimi programları öğretmen adaylarını öğretmenlik mesleğine hazırlamada çeşitli deneyimler sunmaktadır (Tatto, Lerman \& Novotta, 2009). Ancak yine de öğretmen adaylarının pek çoğunun öğretmenlik mesleğine hazır olma konusunda çeşitli kaygılarının bulunduğu görülmektedir (Akgün \& Özgür, 2014; Doğan \& Çoban, 2009; Karakaya, Avgın, Gömlek \& Balık, 2017; Saracaloğlu, Kumral \& Kanma, 2009).

Öğretmen adaylarının öğretmenlik mesleğine ilişkin kaygılarının önemli bir bölümü, mesleğin ilk yıllarında, öğrencilerin ihtiyaçlarına uygun cevap verme, sınıf yönetimini sağlama, mesleğin getirdiği sorunlarla baş etme, okul yaşamının getirdiği günlük sorunların üstesinden gelmeye yönelik endişeler ve öğretmenlik eğitimi boyunca yeterli mesleki deneyimin kendilerine sunulmaması ile ilgilidir (Arslan \& Özpınar, 2008; Stanulis, Fallona \& Pearson, 2002; Thomas \& Kiley, 1994). Araştırmalar, mesleğe yönelik kaygılarla baş etmekte güçlük çeken öğretmen adaylarının mesleğin ilk yıllarında öğretmenliği bırakmayı düşündüklerini göstermektedir (Thomas \& Kiley, 1994). Mesleği bırakmaya yönelik bu eğilimin hem mesleğe yeni başlayan öğretmenlerin hem de öğretmen adaylarının öğretmenlik mesleğine hazır olma durumları ile ilgili olduğu düşünülmektedir. Alanyazındaki çalışmalar mesleğe hazır olan öğretmeni, mesleğin getirdiği zorlukların üstesinden gelen ve mesleki yeterliklere sahip birey olarak tanımlarken (Black, 2003; Mehmetlioğlu \& Haser, 2013), öğretmen adayları için hazırbulunuşluğu mesleğe hazır hissetme kavramı ile açıklamaktadır (Mehmetlioğlu \& Haser, 2013). Araştırmalar öğretmenlerin ve öğretmen adaylarının mesleğe hazır olma durumlarının öğretimin niteliğinde rol oynadığını göstermektedir (Housego, 1990). Bununla birlikte, mesleki hazırbulunuşluk düzeyi yüksek olan öğretmen adaylarının sınıf yönetimi konusunda daha az sorunla karşı karşıya kaldığı bilinmektedir (Li, 1999).

Öğretmen eğitiminin temel amaçlarından birisi, öğretmen adaylarına farklı okul ve sınıflarda etkili öğretim yapabilme becerisini kazandırmaktır (Flores, 2018). Öğretmen adaylarına bu becerinin kazandırılması, genel kültür, alan bilgisi ve meslek bilgisi donanımı ilgili ilgilidir (Demirel, 2012). Buna bağlı olarak, öğretmenlerin, mesleki yeterliklerinin arttırılmasında eğitim programı okuryazarlığı ön plana çıkmaktadır (Bolat, 2017). Eğitim programı okuryazarlığı bazı araştırmacılar tarafından, öğretim programları hakkında bilgi sahibi olma, programı yorumlayabilme, eleştirel bir bakış açısı geliştirme ve öğretim programını öğrenme ortamına uygun biçimde uygulayabilme kapasitesi olarak tanımlanırken (Keskin \& Korkmaz, 2017), bazı araştırmacılar eğitim programı okuryazarlığını öğretmenlerin kendinden beklenen yeterlikleri yerine getirebilmesi olarak tanımlamaktadır (Erdem \& Eğmir, 2018). Bu tanımlardan farklı olarak, bazı araştırmacıların da eğitim programı okuryazarlığını öğretmenin programı yeni durumlara uyarlayabilme kapasitesi olarak tanımladıkları görülmektedir (Nsibande \& Modiba, 2012). Bu tanımlara dayalı olarak eğitim programı okuryazarlığının öğretmenin eğitim programı hakkındaki farkındalığı, programı yorumlayabilme ve etkili bir biçimde uygulayabilme kapasitesi olduğu düşünülmektedir. Öğretmenlerin mesleki hazır olma durumları ve eğitim programı okuryazarlığı hakkındaki bu bilgilerden hareketle, hedef, içerik, öğrenme-öğretme süreçleri ile ölçme ve değerlendirme öğeleri açısından programı etkili olarak tanımlayabilen bir öğretmenin öğretimde daha başarılı, programı bu yönleriyle tanıyan öğretmen adayının da öğretmenliğe hazır olacağı düşünülmektedir. Öğretmen yeterlikleri konusunda elde edilen bu bilgilerden hareketle, eğitim programı okuryazarlığı yüksek olan öğretmen adaylarının öğretmenlik mesleğine yönelik hazırbulunuşluğunun da daha olumlu olacağı düşünülmektedir. Bu durumun, öğrenmeöğretme sürecinin niteliğinin artmasına olumlu katkı sağlayacağı düşünülmektedir.

Alanyazında hem öğretmen hazırbulunuşluğu (Şahin \& Küçüksüleymanoğlu, 2015) hem de eğitim programı okuryazarlığı (Beck, 2013; Bolat, 2017; Karseth \& Sivesind, 2010) konusunda bazı çalışmalar bulunmaktadır. Öğretmen hazırbulunuşluğuna ilişkin çalışmaların önemli bir bölümünün öğretmen adaylarının özyönetimli öğrenme (Karataş, 2017; Karataş \& Başbay, 2014; Şahin, 2010; Şahin \& Küçüksüleymanoğlu, 2015) ya da kendi kendine öğrenmeye yönelik hazırbulunuşluk düzeyleri (Özbek, Eroğlu \& Donmuş, 2017; Salaş, 2010) ile teknoloji hazırbulunuşluğu (Hung, 2016; Instefjord \& Munthe, 2016; Msila, 2015; Oliver, 2010; Singh \& Chan, 2014) ve 
matematik-fen konularındaki hazırbulunuşluğuna (Alkan \& Erdem, 2013; Ng, 2013; Steele, Brew, Rees \& Ibrahim-Khan, 2013) yönelik oldukları görülmektedir. Bununla birlikte, öğretmen adaylarının mesleğe hazırbulunuşluk düzeyleri ile eğitim programı okuryazarlıklarını konu alan bir çalışma olmadığı anlaşılmaktadır. Araştırmalar, mesleğe hazır olan öğretmenlerin uygulanan programları tanıyan ve etkili olarak uygulayabilen öğretmenler olduklarına dikkati çekmektedir (Ingvarson, Beavis \& Kleinhenz, 2007). Bu nedenle öğretmenlik mesleğine hazır olmada öğretmenin kullanacağı öğretim programlarını tanıması ve etkili olarak uygulayabilme becerisinin gelişmiş olmasının önemli olduğu düşünülmektedir. Bu bilgilerden hareketle, bu araştırmada öğretmen adaylarının eğitim programı okuryazarlık düzeylerinin öğretmenlik mesleğine hazır olma durumlarını yordamadaki rolüne odaklanıımıştır. Bu doğrultuda araştırmanın alt amaçları aşağıdaki gibi belirlenmiştir:

1. Öğretmen adaylarının öğretmenlik mesleği hazırbulunuşluğu ve eğitim programı okuryazarlıkları ne düzeydedir?

2. Öğretmen adaylarının öğretmenlik mesleği hazırbulunuşluk düzeyleri cinsiyete, öğrenim görmekte oldukları bölüme ve öğrenim görmekte oldukları sınıf düzeyine göre anlamlı farklılık göstermekte midir?

3. Öğretmen adaylarının eğitim programı okuryazarlık düzeyleri cinsiyete, öğrenim görmekte oldukları bölüme ve öğrenim görmekte oldukları sınıf düzeyine göre anlamlı farklılık göstermekte midir?

4. Öğretmen adaylarının öğretmenlik mesleği hazırbulunuşluk düzeyleri ile eğitim programı okuryazarlık düzeyleri arasında ilişki bulunmakta mıdır?

5. Öğretmen adaylarının eğitim programı okuryazarlık düzeyleri öğretmenlik mesleği hazırbulunuşluk düzeyinin anlamlı bir yordayıcısı mıdır?

\section{Yöntem}

Öğretmen adaylarının, öğretmenlik mesleğine yönelik hazırbulunuşluk düzeyleri ile eğitim programı okuryazarlık düzeyleri arasındaki ilişkiye odaklanan bu araştırma, yordayıcı korelasyonel modelde gerçekleştirilmiştir (Büyüköztürk, Çakmak, Akgün, Karadeniz \& Demirel, 2012). Bu doğrultuda, öğretmen adaylarının eğitim programı okuryazarlık düzeylerinin öğretmenlik mesleğine hazırbulunuşluk düzeylerini anlamlı bir biçimde yordayıp yordamadığı incelenmiştir.

\section{Evren ve Örneklem}

Araştırmanın evrenini Marmara Bölgesi'nde yer alan bir üniversitede öğrenim görmekte olan öğretmen adayları oluşturmaktadır. İlgili fakültede öğrenim gören öğretmen adaylarının tümü çalışmaya katılmak için eşit şansa sahiptir. Bu nedenle, araştırmaya katılacak öğretmen adaylarının belirlenmesinde seçkisiz örnekleme yönteminden olan tabakalı örnekleme tekniği kullanılmıştır (Büyüköztürk et al., 2012). Buna bağlı olarak, örneklemin evreni temsil edebilmesi için \%95'lik güven aralığı kabul edilmiş ve Krejcie ve Morgan (1970) örneklem büyüklüğünü belirleme formülü esas alınmıştır. Araştırmanın, yürütüldüğü Eğitim Fakültesi’nde yaklaşık 3800 civarı öğretmen adayı öğrenim görmektedir. Bununla birlikte üçüncü ve dördüncü sınıfta öğrenim gören toplam öğretmen adaylı sayısı 1524'tür. Yukarıda belirtilen formüle göre 1600 kişilik evren büyüklüğü için 310 kişilik örneklem önerilmiştir. Ancak araştırmada sınıf düzeyi değişkeni de incelendiğinden ve bazı anabilim dallarındaki mevcudun diğerlerine göre daha fazla olmasından dolayı çalışmaya 708 öğretmen adayı katılmıştır. Ayrıca, öğretmen adaylarına kısaca araştırmanın amacı açıklandıktan sonra çalışmaya katılmaya gönüllü olanların ölçme araçlarını doldurmaları sağlanmıştır. Katılımcıların öğrenim görmekte oldukları bölüme göre sayı ve yüzdeleri Tablo 1'deki gibidir:

Tablo 1.

Evren ve Örneklemin Bölüme Göre Frekans ve Yüzde Dağılımı.

\begin{tabular}{lrrr}
\hline & & \multicolumn{2}{c}{ Örneklem } \\
\cline { 2 - 4 } Bölüm & Evren & $\mathbf{f}$ & $\%$ \\
\hline Sınıf Eğitimi & 271 & 211 & 29.40 \\
Okul Öncesi Eğitimi & 306 & 81 & 11.30 \\
Türkçe Eğitimi & 205 & 88 & 12.30 \\
İngilizce Eğitimi & 199 & 108 & 14.80 \\
Psikolojik Danışmanlık ve Rehberlik Eğitimi & 196 & 94 & 13.30 \\
Bilgisayar Öğretmenliği ve Teknoloji Eğitimi (BÖTE) & 175 & 46 & 7.80 \\
Fen Bilgisi Eğitimi & 172 & 80 & 11.10 \\
Toplam & 1524 & 708 & 100.00 \\
\hline
\end{tabular}


Araştırmaya Sınıf Eğitimi ( $n=211)$, Okul Öncesi Eğitimi $(n=81)$, Türkçe Eğitimi $(n=88)$, İngilizce Eğitimi ( $n=$ 108), Psikolojik Danışmanlık ve Rehberlik Eğitimi $(n=94)$, Bilgisayar Öğretmenliği ve Teknoloji Eğitimi $(n=46)$ ve Fen Bilgisi Eğitimi $(n=80)$ Anabilim Dalı́nda öğrenim görmekte olan toplam 708 öğretmen adayı katılmıştır. Ayrıca, adayların 423'ü kadın 285'i erkektir. Buna ek olarak, çalışmaya katılan öğretmen adaylarının 364'ü üçüncü sınıfta 344'ü dördüncü sınıfta öğrenim görmektedir.

\section{Veri Toplama Araçları ve Süreçleri}

Araştırma verilerinin toplanmasında Eğitim Programı Okuryazarlığı Ölçeği (Bolat, 2017) ve Öğretmenlik Mesleğine Yönelik Hazırbulunuşluk Ölçeği (Güven-Yıldırım \& Köklükaya, 2017) kullanılmıştır. Araştırma etiğine uygun gerekli izinlerin tamamlanmasının ardından öğretmen adayları araştırmanın amacı hakkında bilgilendirilmiş ve ölçekler çalışmaya katılmak isteyen gönüllü öğretmen adaylarına dağıtılmıştır. Veri toplama işlemi 2017-2018 akademik yılı bahar yarıyılında gerçekleştirilmiştir.

Eğitim Programı Okuryazarlığı Ölçeği (EPO). Öğretmen adaylarının eğitim programı okuryazarlık düzeylerini belirlemek amacıyla geliştirilen bu ölçme aracı 29 maddeden oluşmaktadır. Ölçme aracının geçerliğini sağlamak amacıyla açımlayıcı ve doğrulayıcı faktör analizinden yararlanılmıştır. Yapılan testler sonucunda ölçme aracının faktör yükü $.40^{\prime}$ ın üzerinde maddelerden oluşan iki faktörde toplandığı görülmüştür. Bu faktörler okuma ve yazma olarak isimlendirilmiştir. Ölçme aracının yapı geçerliğini test etmek amacıyla uygulanan doğrulayıcı faktör analizi sonucunda uyum indekslerinin iyi düzeyde olduğu görülmektedir $\left(X^{2}=657.80 ; p<.05 ; s d=.38\right.$; $\mathrm{RMSEA}=.06 ; \mathrm{SRMR}=.05 ; \mathrm{NFI}=.94 ; \mathrm{NNFI}=.97 ; \mathrm{CFI}=.97 ; \mathrm{IFI}=.97 ; \mathrm{GFI}=.83 ; \mathrm{AGFI}=.80)$. Ölçme aracının iç tutarlıı̆ı̆ın test etmek amacıyla uygulanan güvenirlik analizleri sonucunda Cronbach Alpha katsayısı okuma faktörü için .88, yazma faktörü için .90 ve ölçeğin tamamı için .94 olarak hesaplanmıştır. Katılımcılar, $5^{\prime}$ li Likert tipinde hazırlanan ölçekteki maddelere hiç katılmıyorum, az katılıyorum, orta düzeyde katılıyorum, çok katılıyorum, tamamen katılıyorum ifadelerini kullanarak cevap vermektedir. Ölçeğin puanlanması 1.00-1.80= Kesinlikle katılmıyorum; 1.81-2.60= Katılmıyorum; 2.61-3.40= Kararsızım; 3.41-4.20= Katılıyorum; 4.21-5.00= Kesinlikle katılıyorum şeklindedir.

Öğretmenlik Mesleğine Yönelik Hazırbulunuşluk Ölçeği (OMH). Öğretmen adaylarının öğretmenlik mesleğine yönelik hazırbulunuşluk düzeylerini belirleyebilmek amacıyla geliştirilen bu ölçme aracı 30 maddeden oluşmaktadır. Ölçme aracının geçerliğini sağlamak amacıyla temel bileşenler faktör analizi yönteminden yararlanılmıştır. Böylelikle, faktör yükü .45'in üzerinde olan maddelerin iki alt faktörde toplandığı görülmüştür. Ölçme aracının iç tutarlılığını test etmek amacıyla uygulanan güvenirlik analizleri sonucunda Cronbach Alpha katsayısı birinci faktör için .95, ikinci faktör için .78 ve ölçeğin tamamı için .93 olarak hesaplanmıştır. Bu durum ölçme aracının öğretmen adaylarının öğretmenlik mesleğine hazır olma düzeyini belirlemede geçerli ve güvenilir olduğuna işaret etmektedir. Ölçme aracı 5'li Likert tipindedir. Bu doğrultuda, katılımcılar maddelere kesinlikle katılıyorum, katılıyorum, kararsızım, katılmıyorum ve kesinlikle katılmıyorum ifadeleri aracılığıyla cevap vermektedir. Ölçekten elde edilen puanlar; 1.00 ile 1.80 aralığı: Kesinlikle Katılmıyorum; Çok Düşük Düzey; 1.81 ile 2.60 aralığı: Katılmıyorum; Düşük Düzey; 2.61 ile 3.40 aralığı: Kararsızım; Orta Düzey; 3.41 ile 4.20 aralığı: Katılıyorum; Yüksek Düzey; 4.21 ile 5.00 aralığı: Kesinlikle Katılıyorum; Çok Yüksek Düzey şeklinde yorumlanmıştır.

\section{Verilerin Analizi}

Araştırma verilerinin analizinde öncelikle veri setinin normal dağılıma uygunluğu incelenmiştir. Veri setinin normal dağılım varsayımını karşılama durumuna ilişkin bulgular Tablo 2'de sunulmuştur.

\section{Tablo 2.}

Kolmogorov-Smirnov Testi Sonuçları.

\begin{tabular}{lrrr}
\hline Ölçek & Statistic & sd & Sig. \\
\hline Eğitim Programı Okuryazarlık Ölçeği & .04 & 708 & .20 \\
Öğretmenlik Mesleğine Yönelik Hazırbulunuşluk Ölçeği & .05 & 708 & .11 \\
\hline
\end{tabular}

Araştırmaya katılan öğretmen adaylarının sayısı 29'dan büyük olduğu için Kolmogorov-Smirnov testi uygulanmıştır (Kalaycı, 2010). Yapılan analiz sonucunda p>.05 olduğu için veri setinin normal dağılım gösterdiği anlaşılmaktadır (Field, 2007; Tabachnick \& Fidell, 2007). Bu doğrultuda, parametrik testlerin kullanılmasının uygun olduğuna karar verilmiştir. Buna bağlı olarak, cinsiyet ve sınıf düzeyine ilişkin verilerin incelenmesinde ttesti, bölüme ilişkin verilerin incelenmesinde varyans analizi kullanılmıştır. Öğretmen hazırbulunuşluğu ve 
eğitim programı okuryazarlığı değişkenlerinin birbiri ile olan ilişkisinin incelenmesinde Pearson Korelasyon katsayısı hesaplanmıştır. Ek olarak, öğretmen adaylarının eğitim programı okuryazarlık düzeylerinin, öğretmenlik mesleği hazırbulunuşluk düzeylerini anlamlı bir biçimde yordayıp yordamadığını incelemek amacıyla basit doğrusal regresyon modeli uygulanmıştır.

\section{Bulgular}

Öğretmen adaylarının eğitim programı okuryazarlık ve öğretmenlik mesleğine yönelik hazırbulunuşluk düzeyleri Tablo 3'te sunulmuştur.

Tablo 3.

EPO ve OMH Puanlarının Betimsel Istatistik Sonuçları.

\begin{tabular}{lrrrrrr}
\hline Değişken & N & Min. & Max. & Varyans & Ss. & $\overline{\mathbf{x}}$ \\
\hline EPO & 708 & 2.03 & 5.00 & .29 & .54 & 3.93 \\
OMH & 708 & 1.30 & 5.00 & .25 & .50 & 3.96 \\
\hline
\end{tabular}

Araştırmaya katılan öğretmen adaylarının eğitim programı okuryazarlık ( $\bar{x}=3.93$ ) ve öğretmenlik mesleğine hazırbulunuşluklarının ( $\bar{x}=3.96$ ) Katılıyorum düzeyinde olduğu görülmektedir.

Adayların ölçme araçlarına vermiş oldukları yanıtlar cinsiyet değişkenine göre incelenmiştir. Bulgular Tablo 4'te sunulmuştur.

Tablo 4.

EPO ve OMH Puanlarının Cinsiyet Değişkenine Göre t-testi Sonuçları.

\begin{tabular}{|c|c|c|c|c|c|c|c|}
\hline Değişken & Cinsiyet & $\mathbf{N}$ & $\overline{\mathbf{x}}$ & Ss. & sd & $t$ & $p$ \\
\hline \multirow[t]{2}{*}{ EPO } & Kadın & 423 & 3.96 & .55 & 703 & 2.18 & .03 \\
\hline & Erkek & 285 & 3.86 & .51 & & & \\
\hline \multirow[t]{2}{*}{$\mathrm{OMH}$} & Kadın & 423 & 4.00 & .51 & 703 & 3.92 & .00 \\
\hline & Erkek & 285 & 3.86 & .48 & & & \\
\hline
\end{tabular}

Tablo 4 incelendiğinde öğretmen adaylarının eğitim programı okuryazarlık düzeylerinin $t(708)=2.18, p<.05$ ve öğretmenlik mesleğine hazırbulunuşluk düzeylerinin kadın öğretmen adaylarının lehine anlamlı farklılık gösterdiği anlaşılmaktadır( $\mathrm{t}(708)=3.92, \mathrm{p}<.05)$.

Öğretmen adaylarının ölçme araçlarına vermiş oldukları yanıtların bölüm değişkenine göre anlamlı fark gösterip göstermediğine ilişkin varyans analizi sonuçları Tablo 5’te sunulmuştur.

Tablo 5.

Bölüme Göre EPO ve OMH Puanlarına iliş̧kin Varyans Analizi Sonuçları.

\begin{tabular}{|c|c|c|c|c|c|c|}
\hline Değişken & Varyansın Kaynağı & Kareler Toplamı & sd & Kareler Ortalaması & $\mathbf{F}$ & $p$ \\
\hline \multirow[t]{3}{*}{ EPO } & Gruplar arası & 14.30 & 7 & 2.04 & 7.41 & .00 \\
\hline & Gruplar içi & 191.82 & 701 & .27 & & \\
\hline & Toplam & 206.13 & 708 & & & \\
\hline \multirow[t]{3}{*}{$\mathrm{OMH}$} & Gruplar arası & 6.54 & 7 & .93 & 3.70 & .00 \\
\hline & Gruplar içi & 175.61 & 701 & .25 & & \\
\hline & Toplam & 182.15 & 708 & & & \\
\hline
\end{tabular}

Öğretmen adaylarının eğitim programı okuryazarlık düzeyleri ve öğretmenlik mesleğine hazırbulunuşluk düzeyleri öğrenim görmekte oldukları bölüme göre incelendiğinde Sınıf Eğitimi Anabilim Dalı́nda öğrenim gören öğretmen adaylarının eğitim programı okuryazarlık düzeylerinin ( $\bar{x}=4.05$ ), Okul Öncesi Eğitimi (4.01), Türkçe Eğitimi (3.98), İngilizce Eğitimi (3.84), Rehberlik ve Psikolojik Danışmanlık Eğitimi (3.79), BÖTE (3.65) ve Fen Bilgisi Eğitimi Anabilim Dalı’nda (3.77) öğrenim görmekte olan öğrencilere göre anlamlı farklılık gösterdiği anlaşılmaktadır $F(708)=7.41, p<.05$. Buna ek olarak, öğretmenlik mesleğine ilişkin hazırbulunuşluk düzeyleri incelediğinde, Sınıf Eğitimi Anabilim Dalı'nda öğrenim gören öğretmen adaylarının (4.08), Okul Öncesi Eğitimi $(\bar{x}=4.06)$, Türkçe Eğitimi (3.91), İngilizce Eğitimi (3.89), Rehberlik ve Psikolojik Danışmanlık Eğitimi (3.92), BÖTE (3.72) ve Fen Bilgisi Eğitimi Anabilim Dalı’nda (3.93) öğrenim görmekte olan öğrencilere göre anlamlı farklılık gösterdiği anlaşılmaktadır $F(708)=3.70, p<.05$.

Öğretmen adaylarının vermiş oldukları yanıtlar sınıf değişkenine göre incelendiğinde elde edilen bulgular Tablo 6'da sunulmuştur. 
Tablo 6.

EPO ve OMH Puanlarının Sınıf Değişkenine Göre t-testi Sonuçları.

\begin{tabular}{llcccccc}
\hline Değişken & Sınıf & $\mathrm{N}$ & $\bar{x}$ & Ss. & sd & $t$ & $\mathrm{p}$ \\
\hline EPO & Üçüncü Sınıf & 364 & 3.81 & .54 & 706 & 6.23 & .00 \\
& Dördüncü Sınıf & 344 & 4.06 & .51 & & & \\
OMH & Üçüncü Sınıf & 364 & 3.86 & .48 & 706 & 5.46 & .00 \\
& Dördüncü Sınıf & 344 & 4.07 & .51 & & & \\
\hline
\end{tabular}

Tablo 6 incelendiğinde, dördüncü sınıf öğrencilerinin eğitim programı okuryazarlık düzeylerinin $(\bar{x}=4.06)$ üçüncü sınıf öğrencilerinin eğitim programı okuryazarlık düzeylerinden ( $\bar{x}=3.81$ ) anlamlı farklılık gösterdiği anlaşılmaktadır, $t(708)=6.23, p<.05$. Benzer şekilde, dördüncü sınıf öğrencilerinin öğretmenlik mesleğine hazırbulunuşluk düzeylerinin $(\bar{x}=4.07)$ üçüncü sınıf öğrencilerinin öğretmenlik mesleğine hazırbulunuşluk düzeylerinden ( $\bar{x}=3.86$ ) anlamlı farklılık gösterdiği anlaşılmaktadır $\mathrm{t}(708)=5.46, \mathrm{p}<.05$.

Tablo 7'de öğretmen adaylarının eğitim programı okuryazarlığı ile öğretmenlik mesleğine yönelik hazırbulunuşluk düzeyleri arasındaki ilişkiye yönelik bulgular sunulmuştur.

Tablo 7.

Eğitim Programı Okuryazarlığı ve Öğretmenlik Mesleği Hazırbulunuşluğu Korelasyon Analizi Sonuçları.

\begin{tabular}{llrr}
\hline & & EPO & OMH \\
\hline EPO & Pearson Correlation & 1.000 & $.738\left(^{* *}\right)$ \\
& Sig. (2-tailed) &. & .000 \\
& $N$ & 708 & 708 \\
OMH & Pearson Correlation & $.738\left(^{* *}\right)$ & 1.000 \\
& Sig. (2-tailed) & .000 &. \\
& $N$ & 708 & 708 \\
\hline
\end{tabular}

Tablo 7 incelendiğinde, öğretmen adaylarının Eğitim Programı Okuryazarlığı ve Öğretmenlik Mesleğine Yönelik Hazırbulunuşluk ölçeklerine ilişkin vermiş oldukları cevapların ilişkisi görülmektedir. Bulgular incelendiğinde, öğretmen adaylarının eğitim programı okuryazarlık düzeyleri ile öğretmenlik mesleğine hazırbulunuşluk düzeyleri arasında pozitif yönde yüksek ilişki olduğu anlaşılmaktadır, $r=.738$.

Tablo 8'de öğretmen adaylarının eğitim programı okuryazarlığı düzeylerinin öğretmenlik mesleği hazırbulunuşluk düzeylerini ne ölçüde yordadığına ilişkin elde edilen bulgular yer almaktadır.

Tablo 8.

Eğitim Programı Okuryazarlığının Öğretmenlik Mesleği Hazırbulunuşluğunu Yordamasına ilişkin Basit Doğrusal Regresyon Analizi Sonuçları.

\begin{tabular}{lrrrrrrr}
\hline Değişken & $\mathbf{B}$ & Standart HataB & $\mathbf{R}$ & $\mathbf{R}^{2}$ & Standardize edilmiş $\boldsymbol{\beta}$ & $\mathbf{t}$ & $\mathbf{F}$ \\
\hline Constant & 1.46 & .10 & .68 & .46 & .680 & 14.44 & 615.97 \\
EPO & .635 & .02 & & & & 24.81 & \\
\hline
\end{tabular}

Eğitim programı okuryazarlığının öğretmenlik mesleği hazırbulunuşluğunu yordamadaki rolüne ilişkin basit doğrusal regresyon analizi sonuçlarının anlamlı olduğu görülmektedir ( $F=615.97), p>.05$. Varyans analizi sonucunda ulaşılan bu bulgu eğitim programı okuryazarlığı ve öğretmenlik mesleğine hazırbulunuşluk arasındaki ilişkinin doğrusal olduğuna işaret etmektedir $\left(R=.680, R^{2}=.462, p<.05\right)$. Bu bulguya göre, eğitim programı okuryazarlık düzeyinin öğretmen adaylarının öğretmenlik mesleğine hazırbulunuşluk düzeylerini pozitif yönde anlamlı olarak yordamakta olduğu anlaşımaktadır. Bir diğer ifade ile eğitim programı okuryazarlık düzeyi, öğretmenlik mesleğine hazır olmada toplam varyansın \%46'sını açıklamaktadır.

\section{Tartışma, Sonuç ve Öneriler}

Araştırma bulguları öğretmen adaylarının eğitim programı okuryazarlık düzeylerinin katılıyorum, öğretmenlik mesleğine yönelik hazırbulunuşluk düzeylerinin katılıyorum düzeyinde olduğunu göstermektedir. Bu durum, öğretmen adaylarının eğitim programı okuryazarlık düzeyleri ve öğretmenlik mesleğine yönelik hazırbulunuşluk düzeylerinin çok yüksek olmamakla birlikte iyi düzeyde olduğuna dikkati çekmektedir. Bu bulgunun hem eğitim programı okuryazarlığı (Erdem \& Eğmir, 2018; Sural \& Dedebali, 2018) hem de 
öğretmenlik mesleği hazırbulunuşluğu (Mehmetlioğlu \& Haser, 2013; Şahin \& Küçüksüleymanoğlu, 2015) açısından alanyazındaki benzer çalışmaların bulguları ile uyumlu olduğu anlaşılmaktadır. Bu durumun öğretmen adaylarının mesleki gelişimleri açısından olumlu olduğu düşünülmektedir.

Bulgular cinsiyet değişkeni dikkate alınarak incelediğinde kadın öğretmen adaylarının eğitim programı okuryazarlık düzeyleri ve öğretmenlik mesleğine yönelik hazırbulunuşluk düzeylerinin erkek öğretmen adaylarından daha yüksek olduğu anlaşılmaktadır. Bu bulgunun, öğretmenlik mesleğine yönelik tutumlar ile ilgili olduğu düşünülmektedir. Öğretmen adaylarının mesleğe ilişkin tutumlarını konu alan araştırmalar incelendiğinde, kadın öğretmen adaylarının öğretmenlik mesleğini anneliğe benzettikleri ve bu nedenle mesleğe yönelik tutumlarının erkek adaylara göre daha olumlu olduğu ve öğretmenlik mesleğini erkek adaylara göre daha bilinçli olarak tercih ettikleri görülmektedir (Bozdoğan, Aydın \& Yıldııım, 2007; Budak \& Kula, 2017; Çapri \& Çelikkaleli, 2008; Çermik, Doğan \& Şahin, 2010; Çocuk, Yokuş \& Tanrıseven, 2015; Koç, 2014; Özsoy, Özsoy, Özkara \& Memiş, 2010; Terzi \& Tezci, 2007). Ek olarak, mesleğe ilişkin olumlu tutumları olan öğretmen adaylarının meslek bilgisi derslerinde daha başarıı oldukları bilinmektedir (Ekici, 2008). Bu bilgilerden hareketle, kadın öğretmen adaylarının öğretmen olmaya daha istekli oldukları ve bu nedenle meslek ve alan bilgisi derslerine ilişkin farkındalıklarının erkek öğretmen adaylarına göre daha yüksek olduğu söylenebilir.

Öğretmen adaylarının eğitim programı okuryazarlık düzeyleri ve öğretmenlik mesleğine hazırbulunuşluk düzeyleri öğrenim görmekte oldukları bölüm dikkate alınarak incelediğinde, Sınıf Eğitimi Anabilim Dalı’nda öğrenim gören öğretmen adaylarının eğitim programı okuryazarlık düzeyleri ve öğretmenlik mesleğine hazırbulunuşluk düzeylerinin diğer anabilim dallarında öğrenim gören öğretmen adaylarına göre daha yüksek olduğu anlaşılmaktadır. Sınıf Eğitimi Öğretmen Yetiştirme Lisans Programında; Ilkokuma Yazma Öğretimi, Türkçe Öğretimi, Hayat Bilgisi Öğretimi, Sosyal Bilgiler Öğretimi Fen ve Teknoloji Öğretimi, Matematik Öğretimi Din Kültürü ve Ahlak Bilgisi Öğretimi dersleri yardımıyla öğretmen adayları öğretim programlarını kazanım, beceri, kavram vb. özellikler yönünden incelemektedirler (Yükseköğretim Kurulu, 2006). Diğer öğretmen eğitimi programları incelendiğinde, Okul Öncesi Eğitimi, BÖTE ve Türkçe Eğitimi'nde Özel Öğretim Yöntemleri, İngilizce Eğitimi'nde İngilizce Öğretiminde Yaklaşımlar ve Özel Öğretim Yöntemleri, Fen Eğitimi'nde Fen-Teknoloji Programı ve Planlama ile Özel Öğretim Yöntemleri, PDR'de ise Rehberlikte Program Geliştirme derslerinde alana özgü öğretim programlarının incelendiği anlaşılmaktadır (Yükseköğretim Kurulu, 2006). Öğretmen eğitimi programları karşılaştııılığında, Sınıf Eğitimi alanında öğretim programlarını incelemeye yönelik derslerin oldukça yoğun olduğu görülmektedir. Bu nedenle, öğretmen adaylarının farklı alan eğitimi dersleri aracılığıyla çok sayıda öğretim programını inceleme fırsatı olduğu ve buna bağlı olarak eğitim programı okuryazarlık düzeylerinin diğer öğretmen eğitimi programlarında öğrenim gören öğretmen adaylarına göre daha olumlu olduğu düşünülmektedir. Ayrıca, Sınıf Eğitimi alanında öğrenim gören öğretmen adaylarının mesleki hazırbulunuşluk düzeyleri de diğer öğretmen eğitimi programlarında öğrenim gören öğretmen adaylarına göre daha yüksektir. Bu durumun, alan eğitimi derslerinin katkısından kaynaklandığı düşünülmektedir. Bir diğer ifadeyle, Sınıf Eğitimi alanında öğrenim gören öğretmen adaylarının alan eğitimi derslerine ilişkin okuryazarlık düzeylerinin yüksek olmasının kendilerini mesleğe hazır hissetmesine yardımcı olduğu düşünülmektedir. Alanyazın, alan eğitimi derslerinde başarıı olan Sınıf Öğretmeni adaylarııı öğretmen yeterlik algılarının yüksek olduğuna dikkati çekmektedir (Çaycı, 2011; Ekici, 2008). Dolayısıyla elde edilen bulgunun alanyazındaki benzer çalışmalar ile de uyumlu olduğu anlaşılmaktadır.

Araştırmada dördüncü sınıf öğrencilerinin hem eğitim programı okuryazarlık düzeylerinin hem de öğretmenlik mesleğine hazırbulunuşluk düzeylerinin daha yüksek olduğu bulunmuştur. Bulgunun benzer çalışmaların sonuçları ile paralellik gösterdiği anlaşılmaktadır (Housego, 1992; Mehmetlioğlu \& Haser, 2013). Bu durumun, Öğretmenlik Uygulaması derslerinin öğretmen adaylarına sağlamış olduğu olumlu katkılardan kaynaklandığı düşünülmektedir. Öğretmenlik uygulaması dersinde, öğretmen adayı, lisans eğitimi boyunca öğretmenlik mesleğine ilişkin edindiği bir birçok bilgi ve beceriyi uygulama okullarında yeniden yapılandırmaktadır (Karadüz, Eser, Şahin \& Illbay, 2009). Buna bağlı olarak, aday hem uygulama dersini planlamakta hem de öğretmenliği deneyimlemektedir. Böylece, alan eğitimi derslerinde öğretim programlarına ilişkin edindiği bilgiyi kullanarak ders planı oluşturmakta ve uygulamaktadır. Dolayısıyla, dördüncü sınıfta öğrenim gören öğretmen adaylarıın eğitim programı okuryazarlık düzeyi ve öğretmenlik mesleğine hazırbulunuşluk düzeyinin yüksek olmasının bu duruma bağlı olduğu düşünülmektedir.

Bu araştırmada son olarak eğitim programı okuryazarlı̆̆ı ile öğretmenlik mesleğine yönelik hazırbulunuşluk düzeyi arasında pozitif yönde yüksek ilişki bulunduğu ve eğitim programı okuryazarlık düzeyinin öğretmenlik mesleğine yönelik hazırbulunuşluğu yordadığı saptanmıştır. Daha önce ifade edildiği üzere, alanyazın mesleğe 
hazır olan öğretmeni mesleki yeterliklere sahip birey olarak tanımlamaktadır (Mehmetlioğlu \& Haser, 2013). Buna ek olarak Öğretmenlik Mesleği Genel Yeterlikleri incelendiğinde mesleki bilgi ve mesleki beceriye sahip öğretmen "Alanın öğretim programına ve pedagojik alan bilgisine sahiptir", "Eğitim Öğretim süreçlerini etkin bir şekilde planlar", "Bütün öğrenciler için etkili öğrenmenin gerçekleşebileceği sağlıklı ve güvenli öğrenme ortamları ile uygun öğrenme materyalleri hazırlar" "Öğrenme ve öğretme sürecini etkili bir şekilde yürütür", "Ölçme ve değerlendirme yöntem, teknik ve araçlarııı amacına uygun kullanır" şeklinde tanımlanmaktadır (Öğretmen Yetiştirme ve Geliştirme Genel Müdürlüğü, 2017). Bu bilgiler ışığında, tanımlanan öğretmen yeterliklerinin eğitim programı okuryazarlı̆̆ı ile ilgili olduğu düşünülmektedir. Çünkü eğitim programı okuryazarlığı öğretmen yeterliğinin boyutlarından biridir (Bolat, 2017).

Sonuç olarak araştırmadan elde edilen bulgular genel olarak değerlendirildiğinde, öğretmen adaylarının öğretim programları ile ilgili çalışmaları arttıkça eğitim programı okuryazarlık ve mesleki hazır olma düzeyleri de artmaktadır. Ayrıca, öğretmenlik uygulaması gibi alan çalışmaları adayların eğitim programı okuryazarlığı ve mesleğe hazır olma düzeyleri üzerinde rol oynamaktadır. Buna bağıı olarak, adayların eğitim programı okuryazarlık düzeyleri öğretmenlik mesleğine hazır olma durumlarını yordamaktadır. Yani, alana özgü öğretim programına ilişkin bilgi ve becerisi yüksek olan öğretmen adayları kendilerini mesleğe hazır hissetmektedir.

Alanyazın incelediğinde, genellikle mesleki yeterlikler ile hazırbulunuşluk arasındaki çalışmalar dikkati çekmektedir. Eğitim programı okuryazarlığı ile öğretmenlik hazırbulunuşluğuna odaklanan bu çalışmanın özgün olduğu ve alana katkı sağlayacağı düşünülmektedir. Bu çalışmadan elde edilen bulgulara dayalı olarak, öğretmen adaylarının alana özgü öğretim programı okuryazarlıklarının hazırbulunuşluk üzerindeki rolünün incelenmesi önerilmektedir. 


\section{References}

Akgün, F., \& Özgür, H. (2014). Examination of the anxiety levels and attitudes of the information technology pre-service teachers towards the teaching profession. Journal of Theory and Practice in Education, 10(5), 1206-1223.

Alkan, F., \& Erdem, E. (2013). The effect of self-directed learning on the success, readiness, attitudes towards laboratory skills and anxiety in laboratory. Hacettepe University Journal of Education, 44, 15-16.

Arslan, S., \& Özpınar, İ. (2008). Teachers qualifications: Comparison between primary school curriculum expectations and teachers acquisitions in education faculties. Necatibey Faculty of Education, Electronic Journal of Science and Mathematics Education, 2(1), 38-63.

Başal, H. A., \& Taner, M. (2003, September). Okul öncesi eğitimi öğrencilerinin akademik başarıları ile mezun oldukları lise türü ve mezuniyet dereceleri arasındaki ilişki [The relationship between the academic achievement of pre-school education students and the grade of high school and graduation grade they graduate]. Proceedings of OMEP Dünya Konsey Toplantısı ve Konferansı (pp. 482-489). İstanbul: Yapa Yayıncılık.

Beck, J. (2013). Powerful knowledge, esoteric knowledge, curriculum knowledge. Cambridge Journal of Education, 43(2), 177-193.

Black, M. W. (2003). A study of first-year teachers and their principals: perceptions of readiness among participants from traditional and non-traditional teacher preparation programs. Unpublished doctoral dissertation, Fayetteville State University.

Bolat, Y. (2017). Concept of curriculum literacy and curriculum literacy scale. International Periodical for the Languages, Literature and History of Turkish or Turkic, 12(18), 121-138.

Bozdoğan, A. E., Aydın, D., \& Yıldırım, K. (2007). Attitudes of teacher candidates towards teaching profession. Ahi Evran Üniversitesi Kırşehir Eğitim Fakültesi Dergisi, 8(2), 83-97.

Budak, Y., \& Kula, S. S. (2017). Perceptions of teacher candidates about teaching as a profession. Ahi Evran Üniversitesi Kırşehir Eğitim Fakültesi Dergisi, 18(2), 311-329.

Büyükkaragöz, S. S., Muşta, M. C., Yılmaz, H., \& Pilten, Ö. (1998). Öğretmenlik mesleğine giriş (Eğitimin temelleri) [Introduction to Teaching Profession]. Konya: Mikro Yayınları.

Büyüköztürk, Ş., Çakmak-Kılıç, E., Akgün, Ö. E., Karadeniz, Ş., \& Demirel, F. (2012). Bilimsel araştırma yöntemleri [Sciencitific Research Methods] (13th Ed.). Ankara: Pegem.

Çapri, B., \& Çelikaleli, Ö. (2008). Investigation of pre-service teachers' attitudes towards teaching and professional self-efficacy beliefs according to their gender, programs, and faculties. Inonu University Journal of the Faculty of Education, 9(15), 33-53.

Çaycı, B. (2011). Investigation of the effect of the field education courses on the teacher's qualification in the primary school teacher education. Mersin University Journal of The Faculty of Education, 7(2), 1-12.

Çermik, H., \& Şahin, B. D. A. (2010). Prospective elementary classroom teachers' motives for selecting teaching profession. Pamukkale University Journal of Education, 28(28), 201-212.

Çocuk, H. E., Yokuş, G., \& Tanrıseven, I. (2015). Pedagogical formation students' self-efficacy and metaphoric perceptions related to teaching profession. Mustafa Kemal University Journal of Social Sciences Institute, 12(32), 373-387.

Demirel, Ö. (2012). Öğretim ilke ve yöntemleri öğretme sanatı (19th ed.) [Teaching principles and methods teaching art]. Ankara: Pegem Akademi.

Doğan, T., \& Çoban, A. E. (2009). The investigation of the relations between students' attitude toward teaching profession and anxiety level in faculty of education. Education and Science, 34(153), 157-168.

Ekici, G. (2008). Effects of classroom management lesson on preservice teacher' attitudes and beliefs on classroom control. Çukurova University Journal of Social Sciences Institute, 17(3), 167-182.

Erdem, C., \& Eğmir, E. (2018). Öğretmen adaylarının eğitim programı okuryazarlığı düzeyleri. Afyon Kocatepe University Journal of Social Sciences, 20(2),123-138.

Field, A. (2013). Discovering statistic using SPSS (4th ed.). London: SAGE. 
Flores, M. A. (2018). Conditions for professional learning in teacher education. European Journal of Teacher Education, 41(3), 263-265.

Güven-Yıldırım, E., \& Köklükaya, A. N. (2017). Development of readiness scale for teaching profession and determination of science teacher candidates' readiness levels. The Journal of Academic Social Science Studies, 56, 67-82.

Housego, B. (1992). Monitoring student teachers' feelings of preparedness to teach and teacher efficacy in a new elementary teacher education program. Journal of Education for Teaching, 18(3), 259- 272.

Housego, B. (1990). Student teachers' feelings of preparedness to teach. Canadian Journal of Education, 15(1), 37-56.

Hung, M. L. (2016). Teacher readiness for online learning: Scale development and teacher perceptions. Computers and Education, 94, 120-133.

Ingvarson, L., Beavis, A., \& Kleinhenz, E. (2007). Factors affecting the impact of teacher education programmes on teacher preparedness: Implications for accreditation policy. European Journal of Teacher Education, 30(4), 351-381.

Instefjord, E., \& Munthe, E. (2016). Preparing pre-service teachers to integrate technology: An analysis of the emphasis on digital competence in teacher education curricula. European Journal of Teacher Education, 39(1). 77-93.

Kalaycı, Ş. (2010). SPSS uygulamalı çok değişkenli istatistik teknikleri [Multivariate statistical techniques with SPSS]. Ankara: Asil Yayın Dağıtım.

Kaptan, F. (1999). Fen bilgisi öğretimi [Science teaching]. İstanbul: Milli Eğitim Basımevi.

Karadüz, A., Eser, Y., Şahin, C., \& İlbay, A. B. (2009). The effectiveness of teaching practice module in opinions of final-year student teachers. Mustafa Kemal University Journal of Social Sciences Institute, 6(11), 442455.

Karakaya, F., Avgın, S. S., Gömlek, E., \& Balık, M. (2017). Examination of pre-service teachers' anxiety levels about teaching profession. International Online Journal of Education and Teaching, 4(2), 162-172.

Karataş, K. (2017). Predicting teacher candidates' self-directed learning in readiness levels for terms of metacognitive awareness levels. Hacettepe University Journal of Education, 32(2), 451-465.

Karataş, K., \& Başbay, M. (2014). Predicting self-directed learning readiness level in terms of critical thinking disposition, general self-efficacy and academic achievement. Elementary Education Online, 13(3), 916-933.

Karseth, B., \& Sivesind, K. (2010). Conceptualising curriculum knowledge within and beyond the national context. European Journal of Education, 45(1), 103-120.

Keskin, A., \& Korkmaz, H. (2017, October). Meaning given to concept of "curriculum literacy" by teachers. Paper presented at the 5th International Conference on Curriculum and Instruction, Muğla, Turkey.

Koç, E. S. (2014). The metaphorical perceptions of classroom teacher candidates regarding teacher and teaching profession concepts. Inonu University Journal of the Faculty of Education, 15(1), 47-72.

Krejcie, R. V., \& Morgan, D. W. (1970). Determining sample size for research activities. Educational and Psychological Measurement, 30(3), 607-610.

Li, X. (1999). Preparedness to teach: a comparison between consecutive and concurrent education students. Alberta Journal of Educational Research, 45(2), 184-197.

Mehmetlioğlu, D., \& Haser, Ç. (2013). Preservice elementary mathematics teachers' preparedness for the teaching profession. Pamukkale University Journal of Education, 34(34), 91-102.

Msila, V. (2015). Teacher readiness and information and communications technology (ICT) use in classrooms: A South African case study. Creative Education, 6(18). 1973.

Ng, K. E. D. (2013). Teacher readiness in mathematical modelling: are there differences between pre-service and in-service teachers? In G. A. Stillman, G. Kaiser, W. Blum and J. P. Brown (Eds.), Teaching mathematical modelling: Connecting to research and practice (pp. 339-348). Dordrecht: Springer.

Nsibande, R. N., \& Modiba, M. M. (2012). I just do as expected. teachers' implementation of continuous assessment and challenges to curriculum literacy. Research Papers in Education, 27(5), 629-645. 
Oliver, K. (2010). Evaluating teacher readiness for the implementation of one-to-one computing based on national educational technology standards. Journal of Literacy and Technology, 11(3), 40-76.

Öğretmen Yetiştirme ve Geliştirme Genel Müdürlüğü [General Directorate of Teacher Training and Development]. (2017). Öğretmenlik mesleği genel yeterlikleri [Teaching profession competence]. Retrieved from https://oygm.meb.gov.tr/meb iys dosyalar/2017 12/11115355 YYRETMENLYK_MESLEYY GENEL_YETERL YKLERY.pdf.

Özbek, R., Eroğlu, M., \& Donmuş, V. (2017). Investigation of teacher candidates' readinesses for self-directed learning. International Journal of Curriculum and Instructional Studies, 7(13), 17-36.

Özsoy, G., Özsoy, S., Özkara, Y., \& Memiş, A. D. (2010). Factors affecting pre-service teachers' choice of teaching as a profession. Elementary Education Online, 9(3), 201-212.

Salaş, G. (2010). Teacher candidates? self-directed learning readinesses (Anadolu University sample). Unpublished master thesis. Anadolu University, Eskişehir.

Saracaloğlu, A. S., Kumral, O., \& Kanma, A. (2009). Anxieties, academic motivation levels and competencies at teaching profession of students at secondary education fields teaching nonthesis master program. Van Yüzüncü Yıl University Journal of Education, 6(2), 38-54.

Singh, T. K. R., \& Chan, S. (2014). Teacher readiness on ICT integration in teaching-learning: A Malaysian case study. International Journal of Asian Social Science, 4(7), 874-885.

Stanulis, R. N., Fallona, C. A., \& Pearson, C. A. (2002). Am I doing what I am supposed to be doing? Mentoring novice teachers through the uncertainties and challenges of their first year of teaching. Mentoring and Tutoring, 10(1), 71-81.

Steele, A., Brew, C., Rees, C., \& Ibrahim-Khan, S. 2013. Our practice, their readiness: Teacher educators collaborate to explore and improve pre-service teacher readiness for science and math instruction. Journal of Science Teacher Education, 24(1), 111-131.

Sural, S., \& Dedebali, N. C. (2018). A Study of Curriculum Literacy and Information Literacy Levels of Teacher Candidates in Department of Social Sciences Education. European Journal of Educational Research, 7(2), 303-317.

Şahin, E. (2010). Effects of elementary school classroom teachers? teaching style preferences, genders, lengths of professional service, self-efficacy perceptions and self-directed learning readiness levels on their professional competency. Unpublished doctoral dissertation, Yıldız Teknik University, İstanbul.

Şahin, E., \& Küçüksüleymanoğlu, R. (2015). The relationship between self-directed learning readiness, metacognitive awareness and locus of control and among teacher candidates. Abant izzet Baysal University Journal of Faculty of Education, 15(2), 317-334.

Tabachnick, B. G., \& Fidell, L. S. (2007). Using multivariate statistic (4th Ed.). Boston, MA: Allyn and Bacon.

Tatto, M. T., Lerman, S., \& Novotn, J. (2009). Overview of teacher education systems across the world. In R. Even \& D. L. Ball (Eds.), The professional education and development of teachers of mathematics (pp. 1524). New York: Springer.

Terzi, A. R., \& Tezci, E. (2007). The attitudes of the students towards teaching profession at Necatibey Education Faculty. Educational Administration: Theory and Practice, 52(52), 593-614.

Thomas, B., \& Kiley, M. (1994, February). Concerns of beginning middle and secondary school teachers. Paper presented at the annual conference of the Eastern Educational Research Association, Sarasoto, FL.

Yükseköğretim Kurulu [Council of Higher Education]. (2006). Eğitim fakültesi öğretmen yetiştirme lisans programları [Faculty of education teacher training programs]. Retrieved from http://www.yok.gov.tr/web/guest/icerik//journal_content/56_INSTANCE_rEHF8BIsfYRx/10279/49875. 
